\title{
Editorial
}

\section{Is Japan reluctant to go international?}

Recent symposium (Japan Times, Nov. 19, 1986) discussed the pace of 'internationalization' in Japan. Mr. Kazuo Nukazawa, director of the International Economic Affairs Department of Keidanren said: 'I don't think Japanese on the whole are pleased with the idea of progressing with internationalization.'

Yet, for Japanese business, education and government leaders, 'Internationalization' is an imperative. My own experience shows that Japanese are not reluctant to accept foreigners into their corporations, universities and other institutions, they are not closed to international cooperation and joint programs and they are quite ready to follow the success of their business and 'open up' in other areas as well.

Still, Glen Fukushima, director of Japanese affairs at the office of the U.S. Trade Representative, said about 'internationalization': 'Looking at the various facets of Japanese society, I don't see much hope for change.'

We have confronted some of our Human Systems Management colleagues with the question of internationalization in Japan.

Professor Yoshio Kondo from Kyoto University, leading figure in quality control and management in Japan, expressed doubts about the representativeness of the Japan Times article and sent us a table of foreign scholars, research fellows and students at Kyoto University:

\begin{tabular}{lcccccc}
\hline & 1981 & 1982 & 1983 & 1984 & 1985 & 1986 \\
\hline Foreign scholars & 75 & 46 & 83 & 102 & 96 & 279 \\
Foreign research & & & & & & \\
$\quad$ fellows & 88 & 99 & 123 & 117 & 127 & 147 \\
Foreign students & 174 & 207 & 263 & 286 & 329 & 445 \\
Total & 337 & 352 & 469 & 505 & 552 & 871
\end{tabular}

North-Holland

Human Systems Management 7 (1987) 85-86
The total number of foreigners in 1986 is $260 \%$ of that in 1981. The dynamics of change is obvious, but absolute contribution and effects on 'internationalization' still remain unclear.

One problem is that 'internationalization' is interpreted as simply 'opening up', as some sort of international glasnost' à la Gorbachov. This could misfire because it leads to passive inflow of regressive, conservative and traditional ideas, rather than to active engagement of progressive, modern and future-oriented programs, people and ideas. Internationalization must be viewed as a two-way, active and future-oriented project which would enhance rather than retard the Japanese society.

Professor Akira Ishikawa of Aoyama Gakuin University pointed out the 'pendulum' character of the 'internationalization/nationalization' debate in Japan. He underlined the need for continued visits, lectures, seminars and joint projects - sharing the future vision and working on it together.

Professor Shigeo Minabe from Hiroshima University also responded to the question of Japan's reluctance to go international with an emphatic denial.

Why is it that the symposium at the International House of Japan must reach an entirely different conclusion than our Japanese university colleagues?

Mr. Kazuo Nakamura of Industrial Products Research Institute calls 'internationalization' tatemae (one's expressed principle) supported by business requirements. But he points out lack of deeper interests in history, philosophy and humanism of other countries.

Professor Minabe reminds us that Japan has never initiated its own culture and as a consequence Japanese have become reluctant to bring Japanese culture out, before the rest of the world. Japanese are not sure what being 'true' Japanese means. In many areas there is a strong inferiority complex and view of Japan as 'big countryside'. 
Being Japanese cannot mean loincloth, kimono, sumo, tea ceremony, geishas, bonfires, sushi and Shinto music. That is not Japanese culture in modern, international sense. Not just that.

Japanese culture means sensitivity to global and local 'business ecology', gentleness and respect in human conduct, dedication to quality, pride in good work - and, hopefully, in good life too: knowing not only how to earn but also how to spend, participating in world affairs and concerns.

Japanese are the 'new rich' of the world, with all the uncertainties, weaknesses, snobism, and even vulgarity of such culture-free and history-free condition. But there is also this great potential to become a truly great nation and truly great culture. And that cannot be carried out without 'internationalization'.

Japanese have to start learning, soon and vigorously, from the past mistakes, failures and disappointments of other 'newly rich' nations before them. Living affluently, but in ignorance, isolation and self-congratulation - how many countries have fallen in the same trap? What are the human, moral and cultural cost of such mistake? We only know that they are enormous.

Let the well-known caricature of a rich American, ignorant in languages or culture, unable to give anything other than money, eternally embarassed, forever self-doubting, and always at the moral edge - let that be a warning to all of us, including Japan.

It is not too late to open up to the best in the world and to open free markets not only to goods but to good ideas as well.

Let us act as if the rest of the world really mattered ... because it does.
Internationalization is of course Japanese problem. But the international friends can help. How?

Let us stop treating Japan as an interesting and even bizarre (as they often view the rest of the world themselves) object of study. There is enough of Japan studies, Japan institutes, and Japan culture houses. Japanese are being observed, described, analyzed, photographed and copied: they are under the microscope like some modern 'guinea pigs' of the worldwide 'Japan research'.

Rarely we establish institutions with the Japanese as joint and equal partners, rarely we resist the urge to observe them and study them. Such efforts cannot contribute a thing to the much needed self-confidence of the 'new rich'. Japanese themselves support and even fund such 'institutes for Japan studies', as if they themselves desired to be observed, analyzed and described. To me, that is not 'internationalization'.

Internationalization means to become an internationally respected, self-confident and globally sensitive citizen of the world. That can only grow from a deep sense of self-worth and from a strong sense of non-local, sharing and contributory culture.

Japanese today have the potential and capabilities to become such people, perhaps for the first time in human history. It could even become a national project of sorts, many times surpassing any 'Fifth generation' in both importance and value.

But then, they might not succeed ...

Milan ZELENY

Fordham University at Lincoln Center New York, NY 10023, U.S.A. 